Jurnal Penelitian dan Evaluasi Pendidikan

\title{
EVALUASI PROGRAM PENINGKATAN KULAIFIKASI GURU MADRASAH DI SUMATERA SELATAN
}

\author{
Nyayu Khodijah \\ Fakultas Tarbiyah IAIN Raden Fatah Palembang \\ nyayu-dd@yahoo.com
}

\begin{abstract}
Abstrak
Penelitian ini bertujuan untuk mengevaluasi program peningkatan kualifikasi guru, khususnya yang dilaksanakan oleh Kementerian Agama terhadap guru madrasah, dan untuk menilai apakah program yang berjalan telah memberikan dampak yang diharapkan. Penelitian dilakukan menggunakan metode deskriptif evaluatif menggunakan model evaluasi konteks, input, proses dan produk (context, input, process, product, CIPP), dan difokuskan pada evaluasi proses dan produk. Penelitian dilaksanakan di provinsi Sumatera Selatan. Responden penelitian ini adalah guru madrasah yang menjadi peserta program kualifikasi angkatan pertama. Pengumpulan data dilakukan menggunakan teknik angket dan wawancara, sedang analisis data menggunakan teknik analisis kuantitatif. Hasil penelitian menunjukkan bahwa pelaksanaan program peningkatan kualifikasi guru madrasah sebagian besar telah berjalan sesuai dengan yang direncanakan. Namun, bila dilihat satu per satu, khusus pada proses pelaksanaannya masih ada beberapa hal yang belum sepenuhnya sesuai dengan yang direncanakan. Dampak yang dirasakan oleh guru dengan diterapkannya program ini terlihat pada peningkatan kompetensi mengajar, peningkatan karir, serta peningkatan kesejahteraan, tapi dampaknya pada kemungkinan penerapan materi perkuliahan yang diperoleh masih belum optimal.
\end{abstract}

Kata kunci: guru madrasah, program peningkatan kualifikasi guru 


\title{
EVALUATION OF MADRASAH TEACHERS' QUALIFICATIONS IMPROVEMENT PROGRAM IN SOUTH SUMATRA
}

\author{
Nyayu Khodijah \\ Fakultas Tarbiyah IAIN Raden Fatah Palembang \\ nyayu-dd@yahoo.com
}

\begin{abstract}
This study aimed to evaluate the program of improving teacher qualifications, especially those implemented by the Ministry of Religious Affairs of the madrasah teachers, and to assess whether the program has given the expected impact. The study was conducted by using descriptive evaluative method. The research was conducted in South Sumatra province. The respondents were all madrasah teachers who became the first group participants in that program. Data collection techniques used were questionnaire and interview, data analysis techniques used are of quantitative analysis. The results showed that the program for improving teacher qualifications had been running largely as planned. However, when viewed one by one, specifically on the implementation process there are still many things that are not completely as planned. Moderate impact felt by the teachers can be seen at improving teaching competencies, improving careers, as well as improving the welfare, but still less on the possibility of applying materials obtained from lecturing.
\end{abstract}

Keywords: madrasah teachers, the program for improving teacher qualifications 


\section{Pendahuluan}

Madrasah merupakan lembaga pendidikan yang dalam beberapa hal memiliki banyak kekurangan. Di antara kelemahan terpenting yang dimiliki madrasah adalah rendahnya kualitas lulusan madrasah. Rendahnya kualitas lulusan madrasah tampak dari masih rendahnya prosentase siswa yang dapat melanjutkan ke jenjang pendidikan yang lebih tinggi. Hanya 88,7\% lulusan MI dapat melanjutkan ke MTs, SMP atau Pesantren; 63,9\% lulusan MTs melanjutkan ke MA, SMA, SMK atau Pesantren, dan hanya 35,6\% lulusan MA dapat melanjutkan ke Perguruan Tinggi (Depag, 2007: 3).

Ada banyak hal yang menyebabkan kompetensi lulusan madrasah itu rendah, diantaranya adalah karena kondisi guru madrasah yang kurang mendukung. Diantara kondisi yang cukup memprihatinkan adalah kualifikasi sebagian besar guru madrasah yang masih berada di bawah S1/D4. Berdasarkan data Direktorat Pendidikan pada Madrasah Dirjen Pendidikan Islam Depag RI tahun 2007, dari 584.095 orang guru madrasah, hanya 224.886 (38,5\%) saja yang memiliki kualifikasi S1. Bila dilihat untuk masing-masing jenjang, hanya $6,9 \%$ guru RA yang memiliki kualifikasi S1, 16,8\% untuk guru MI, 54,6\% untuk guru MTs, dan 72\% untuk guru MA. Dari angka-angka tersebut jelas terlihat masih belum memadainya kualifikasi guru madrasah.

Menyadari pentingnya peningkatan kualifikasi guru dalam rangka mengejar ketertinggalan kualitas lulusan madrasah, Kementerian Agama memberikan prioritas tersendiri pada upaya peningkatan kualifikasi guru madrasah. Dengan meningkatnya kualifikasi guru diharapkan mampu meningkatkan kualitas guru. Peningkatan kualitas guru ini menjadi bagian dari arah kebijakan strategis pengembangan kualitas madrasah. Sejalan dengan arah kebijakan tersebut, salah satu program peningkatan kualitas guru madrasah yang dilaksanakan Kementerian Agama adalah program peningkatan kualifikasi guru ke jenjang S1/D-4 melalui kerjasama dengan LPTK. Program ini ditujukan untuk membantu guru madrasah dalam meningkatkan kualifikasi akademiknya sesuai dengan amanah Peraturan Pemerintah Nomor 19 Tahun 2005 tentang Standar Nasional Pendidikan. 
Di Propinsi Sumatera Selatan sendiri, program peningkatan kualifikasi guru madrasah diselenggarakan oleh Fakultas Tarbiyah IAIN Raden Fatah. Program ini sudah berjalan selama \pm 4 tahun. Akan tetapi, sejauh ini belum pernah dilakukan evaluasi eksternal apakah program yang dilaksanakan betul-betul dilaksanakan sesuai harapan dan juga mencapai hasil yang diharapkan. Dalam pengamatan sementara yang dilakukan, ditemukan ada beberapa permasalahan dalam proses pelaksanaan program itu sendiri, baik dari segi persiapan maupun pelaksanaannya. Dalam konteks itulah penelitian ini dipandang sangat signifikan, sebagai upaya mengevaluasi secara komprehensif terhadap pelaksanaan program peningkatan kualifikasi guru madrasah yang sudah berjalan.

Penelitian ini bertujuan untuk mengevaluasi program peningkatan kualifikasi guru, khususnya yang dilaksanakan oleh Kementerian Agama terhadap guru-guru madrasah di propinsi Sumatera Selatan. Kriterianya adalah apakah proses pelaksanaan program peningkatan kualifikasi tersebut telah sesuai dengan perencanaan. Selain itu, penelitian ini juga ditujukan untuk menilai apakah program peningkatan kualifikasi guru madrasah yang berjalan telah memberikan dampak yang diharapkan berdasarkan penilaian guru.

\section{Metode Penelitian}

Penelitian ini dilakukan dengan menggunakan metode deskriptif evaluatif guna mendeskripsikan dan mengevaluasi pelaksanaan program peningkatan kualifikasi guru madrasah berdasarkan standar kriteria perencanaan yang disusun dan tujuan yang hendak dicapai. Model evaluasi yang digunakan adalah model evaluasi CIPP (Context, Input, Process, Product) dari Stufflebeam (1985: 169-179). Mengingat penelitian ini berfokus pada evaluasi pelaksanaan program yang sudah berjalan implementasinya, maka evaluasi dibatasi pada evaluasi proses dan evaluasi produk. Evaluasi proses bertujuan untuk menilai sejauh mana perencanaan yang disusun telah dapat terlaksana dan apa yang harus direvisi. Standar yang digunakan adalah perencanaan yang telah disusun oleh Kemenag. Sedang evaluasi produk bertujuan untuk mengetahui dampak dirasakan oleh guru dengan 
penerapan program tersebut. Standar yang digunakan adalah tujuan penyelenggaraan program sertifikasi guru agama yang telah digariskan oleh Kemenag.

Penelitian dilaksanakan di provinsi Sumatera Selatan. LPTK (PTAI) penyelenggara program peningkatan kualifikasi guru madrasah di provinsi ini adalah Fakultas Tarbiyah IAIN Raden Fatah Palembang. Responden penelitian ini adalah guru madrasah yang menjadi peserta program kualifikasi angkatan pertama yang berjumlah 250 orang, sedang sampelnya adalah 30 orang.

Pengumpulan data menggunakan teknik angket dan wawancara. Teknik angket digunakan untuk menggali data proses pelaksanaan program peningkatan kualifikasi guru madrasah yang sudah berjalan selama ini, sedang wawancara digunakan untuk memperoleh data pelengkap tentang proses pelaksanaan program peningkatan kualifikasi yang belum tergali melalui angket dan untuk menggali data tentang dampak yang dirasakan oleh guru dari pelaksanaan program peningkatan kualifikasi berdasarkan penilaian (judgement) guru. Teknik analisis data yang digunakan adalah teknik analisis kuantitatif dengan menggunakan statistik persentase. Selain itu juga dilakukan analisis kualitatif terhadap data kualitatif yang terkumpul melalui wawancara.

\section{Hasil Penelitian}

\section{Proses Pelaksanaan Program}

Evaluasi terhadap proses pelaksanaan program peningkatan kualifikasi guru madrasah dalam hal ini meliputi evaluasi terhadap persiapan program dan evaluasi terhadap proses pembelajaran.

Dalam hal persiapan program, secara umum hasil evaluasi menunjukkan bahwa persiapan program Peningkatan Kualifikasi Guru Madrasah sebagian besar sudah berjalan sesuai dengan yang direncanakan. Akan tetapi jika dilihat dari masing-masing aspek, beberapa belum sepenuhnya sesuai. Hasil analisis data selengkapnya sebagai berikut: 


\section{Prosedur Penyaluran Bantuan}

Evaluasi terhadap prosedur penyaluran bantuan dalam hal ini meliputi waktu penerimaan bantuan, kesesuaian jumlah bantuan yang diterima, sistem penyaluran dana, efektifitas mekanisme penyaluran dana, kemudahan dalam menerima bantuan biaya pendidikan, serta potongan biaya baik oleh lembaga penyalur (bank) maupun LPTK penyelenggara.

Dilihat dari waktu penerimaan bantuan, diketahui bahwa dari 30 orang sampel guru, 9 orang $(30 \%)$ menyatakan menerima bantuan pada bulan Maret-April, 6 orang (20\%) menyatakan menerimanya di bulan MeiJuni, 5 orang $(16,66 \%)$ menyatakan menerimanya di bulan Januari-Februari, 5 orang $(16,66 \%)$ menyatakan menerimanya di bulan September-Oktober, 4 orang $(13,33 \%)$ menyatakan menerimanya di bulan NopemberDesember, dan hanya 1 orang (3,33\%) menyatakan menerimanya di bulan Juli-Agustus. Dilihat dari kesesuaian jumlah bantuan yang diterima, diketahui bahwa 18 orang (60\%) menyatakan bahwa jumlah bantuan yang diterima tidak sesuai dengan yang seharusnya dan 12 orang (40\%) menyatakan sesuai. Dilihat dari sistem penyaluran dana, diketahui bahwa semua responden $(100 \%)$ menyatakan bahwa dana bantuan yang diterima tidak melalui prosedur pengiriman langsung ke rekening pribadi.

Pada efektifitas mekanisme penyaluran dana, diketahui bahwa 15 orang (50\%) menyatakan bahwa mekanisme penyaluran dana sudah efektif dan 15 orang $(50 \%)$ lainnya menyatakan tidak efektif. Dilihat dari kemudahan dalam menerima bantuan, diketahui bahwa 22 orang $(73,33 \%)$ merasakan kemudahan dalam menerima bantuan yang diberikan dan 8 orang (26,67\%) merasakan tidak mudah. Dilihat dari potongan biaya oleh lembaga penyalur (bank), diketahui bahwa 18 orang (60\%) menyatakan adanya potongan oleh bank. Dilihat dari potongan biaya oleh LPTK penyelenggara program, diketahui bahwa 17 orang (56,67\%) menyatakan adanya potongan oleh LPTK dan 13 orang $(43,33 \%)$ menyatakan tidak ada potongan. 


\section{Prosedur Registrasi}

Evaluasi terhadap prosedur registrasi dalam hal ini meliputi sistem registrasi, sistem seleksi, dan kesulitan dalam memenuhi persyaratan administrasi.

Dilihat dari sistem registrasi untuk menjadi calon penerima bantuan, diketahui bahwa dari 30 orang sampel guru, 28 orang $(93,33 \%)$ menyatakan sistem registrasinya mudah dan hanya 2 orang $(6,67 \%)$ menyatakan sulit/berbelit-belit. Dilihat dari sistem seleksi untuk menjadi calon penerima bantuan, diketahui bahwa 19 orang (63,33\%) menyatakan sistem seleksinya sudah dilakukan sesuai prosedur dan 11 orang (36,67\%) menyatakan tidak sesuai prosedur. Dilihat dari kesulitan dalam memenuhi persyaratan administrasi untuk memperoleh bantuan, diketahui bahwa 20 orang $(66,67 \%)$ menyatakan tidak mengalami kesulitan dan 10 orang $(33,33 \%)$ menyatakan mengalami kesulitan.

Dalam hal proses pembelajaran, secara umum hasil evaluasi menunjukkan bahwa proses pembelajaran pada program Peningkatan Kualifikasi Guru Madrasah sebagian besar sudah berjalan sesuai dengan yang direncanakan. Akan tetapi, jika dilihat dari masing-masing aspek, baik dilihat dari kesiapan dosen dalam mengajar, kualitas pengelolaan perkuliahan, metode pembelajaran, ruang kuliah, fasilitas penunjang proses pembelajaran, sarana dan prasarana, lingkungan kampus, serta pelayanan akademik dan administrasi, beberapa belum sepenuhnya sesuai. Hasil analisis data selengkapnya sebagai berikut:

\section{a. Kesiapan Dosen Dalam Mengajar}

Evaluasi terhadap kesiapan dosen dalam mengajar dalam hal ini meliputi kesesuaian bidang keahlian dosen dengan mata kuliah yang diajarkan, tingkat kualifikasi pendidikan dosen, rata-rata pemahaman dosen terhadap kurikulum, rata-rata kesiapan dosen dalam kelengkapan dokumen perangkat pembelajaran, rata-rata kesiapan dosen dalam merancang tugastugas, waktu luang untuk memberikan bimbingan akademik, ketepatan waktu mengajar sesuai jadwal, serta ketepatan waktu memberikan nilai hasil belajar mahasiswa sesuai jadwal. 
Dilihat dari kesesuaian bidang keahlian dosen dengan mata kuliah yang diajarkan, diketahui bahwa dari 30 orang sampel guru, 15 orang $(50 \%)$ menyatakan bahwa kesesuaian bidang keahlian dosen dengan mata kuliah yang diajarkan berkisar antara $75 \%$ - 99\%, 9 orang (30\%) menyatakan kesesuaiannya berkisar antara 50\% - 74\%, 3 orang (10\%) menyatakan kesesuaiannya sudah $100 \%$, dan 3 orang $(10 \%)$ menyatakan kesesuaiannya $<50 \%$. Mengkaji tingkat kualifikasi pendidikan dosen, diketahui bahwa 12 orang (40\%) menyatakan bahwa 75\% - 99\% berkualifikasi pendidikan S2 ke atas, 9 orang (30\%) menyatakan kurang dari $50 \%$ dosen yang berkualifikasi pendidikan S2 ke atas, 6 orang (20\%) menyatakan 100\% dosen sudah berkualifikasi pendidikan S2 ke atas, dan 3 orang $(10 \%)$ menyatakan bahwa dosen yang berkualifikasi pendidikan S2 ke atas sebanyak 50\% - 74\%.

Dilihat dari tingkat pemahaman dosen terhadap kurikulum, diketahui bahwa 16 orang $(53,33 \%)$ menyatakan tingkat pemahaman dosen terhadap kurikulum berada dalam kategori baik, 12 orang (40\%) menyatakan cukup, 2 orang $(6,66 \%)$ menyatakan sangat kurang, dan yang menyatakan kurang tidak ada sama sekali. Kesiapan dosen terhadap dokumen perangkat pembelajaran, diketahui bahwa 20 orang $(66,66 \%)$ menyatakan kesiapan dosen mencapai 75 - 90\%, 7 orang $(23,33 \%)$ menyatakan kesiapan dosen lebih dari $90 \%, 3$ orang (10\%) menyatakan kesiapan dosen antara $50-74 \%$, dan yang menyatakan kesiapan dosen terhadap dokumen perangkat pembelajaran kurang dari 50\% tidak ada sama sekali.

Dilihat dari kesiapan dosen dalam merancang tugas-tugas, diketahui bahwa 18 orang (60\%) menyatakan kesiapan dosen mencapai $75-90 \%, 6$ orang $(20 \%)$ menyatakan kesiapan dosen lebih dari $90 \%, 6$ orang $(20 \%)$ menyatakan kesiapan dosen antara 50 - 74\%, dan yang menyatakan kesiapan dosen dalam merancang tugas-tugas kurang dari 50\% tidak ada sama sekali. Dilihat dari waktu luang dosen untuk memberikan bimbingan akademik di luar jam kuliah, diketahui bahwa 14 orang (46,67\%) menyatakan hanya sebagian kecil dosen yang mempunyai waktu untuk memberikan bimbingan akademik di luar jam kuliah, 10 orang $(33,33 \%)$ menyatakan tidak ada dosen yang mempunyai waktu untuk memberikan 
bimbingan akademik di luar jam kuliah, 4 orang (13,33\%) menyatakan sebagian besar dosen mempunyai waktu untuk memberikan bimbingan akademik di luar jam kuliah, dan 2 orang $(6,67 \%)$ menyatakan rata-rata dosen mempunyai waktu untuk memberikan bimbingan akademik di luar jam kuliah.

Dilihat dari ketepatan waktu dosen dalam mengajar, diketahui bahwa 16 orang $(53,33 \%)$ menyatakan sebagian besar dosen mengajar sesuai dengan jadwal, 6 orang $(20 \%)$ menyatakan rata-rata dosen mengajar sesuai dengan jadwal, 5 orang $(16,67 \%)$ menyatakan hanya sebagian kecil dosen yang mengajar sesuai dengan jadwal, dan 3 orang (10\%) menyatakan tidak ada dosen yang mengajar sesuai jadwal. Dilihat dari ketepatan waktu dosen dalam memberikan nilai, diketahui bahwa 14 orang (46,67\%) menyatakan rata-rata dosen memberikan nilai tepat waktu, 11 orang (36,67\%) menyatakan sebagian besar dosen memberikan nilai tepat waktu, 4 orang $(13,33 \%)$ menyatakan tidak ada dosen yang memberikan nilai tepat waktu, dan 1 orang (3,33\%) menyatakan hanya sebagian kecil dosen yang memberikan nilai tepat waktu.

\section{b. Kualitas Pengelolaan Perkuliahan}

Evaluasi terhadap kualitas pengelolaan perkuliahan dalam hal ini meliputi pola pengelolaan perkuliahan yang digunakan dosen, penerapan program remedial, pengayaan, dan percepatan dalam implementasi prinsip-prinsip pembelajaran tuntas, respon dan antusiasme mahasiswa program peningkatsn kualifikasi guru dalam perkuliahan, dan interaksi dosen dan mahasiswa dalam proses perkulihan di dalam kelas.

Dilihat dari pola pengelolaan perkuliahan yang digunakan dosen, diketahui bahwa dari 30 orang sampel guru, 13 orang (43,34\%) menyatakan dosen menggunakan gabungan pola individual dan kelompok, 10 orang (33,33\%) menyatakan menggunakan pola kelompok belajar, 7 orang $(23,33 \%)$ menggunakan pola klasikal, dan yang menyatakan dosen menggunakan pola individual tidak ada sama sekali. Dilihat dari penerapan program remedial, pengayaan, dan percepatan dalam implementasi prinsipprinsip pembelajaran tuntas, diketahui bahwa 17 orang $(56,67 \%)$ menyatakan bahwa penerapan program tersebut dalam proses 
pembelajaran oleh dosen berada dalam kategori cukup, 7 orang $(23,33 \%)$ menyatakan kurang, 6 orang $(20 \%)$ menyatakan sudah baik, dan yang menyatakan tidak adanya penerapan program tersebut tidak ada sama sekali.

Dilihat dari respon dan antusiasme mahasiswa, diketahui bahwa 21 orang $(70 \%)$ menyatakan bahwa respon dan antusiasme mahasiswa dalam proses pembelajaran berada dalam kategori baik, 5 orang $(16,67 \%)$ menyatakan cukup, 4 orang $(13,33 \%)$ menyatakan kurang, dan yang menyatakan respon dan antusiasme mahasiswa sangat kurang tidak ada sama sekali. Dilihat dari interaksi dosen dan mahasiswa dalam proses perkuliahan di kelas, diketahui bahwa 24 orang (80\%) menyatakan bahwa interaksi dosen dan mahasiswa dalam proses perkuliahan di kelas berada dalam kategori baik, 4 orang (13,33\%) menyatakan cukup, 2 orang $(6,67 \%)$ menyatakan kurang, dan yang menyatakan interaksi dosen dan mahasiswa sangat kurang tidak ada sama sekali.

\section{c. Metode Pembelajaran}

Evaluasi terhadap metode pembelajaran dalam hal ini meliputi frekuensi penggunaan multimedia/ICT dalam perkuliahan serta penggunaan metode pembelajaran yang bervariasi.

Dilihat dari frekuensi penggunaan multimedia, diketahui bahwa 24 orang $(80 \%)$ menyatakan bahwa frekuensi penggunaan multimedia dalam proses pembelajaran sering dilakukan, 4 orang (13,33\%) menyatakan kadang-kadang saja, 2 orang (6,67\%) menyatakan jarang, dan yang menyatakan tidak pernah tidak ada sama sekali. Dilihat dari penggunaan penggunaan metode pembelajaran yang bervariasi, diketahui bahwa 13 orang $(43,34 \%)$ menyatakan bahwa hanya sebagian kecil dosen yang mengajar dengan metode bervariasi, 10 orang (33,33\%) menyatakan ratarata dosen mengajar dengan metode bervariasi, 7 orang (23,33\%) menyatakan sebagian besar dosen mengajar dengan metode bervariasi, dan yang menyatakan metode mengajar dosen tidak bervariasi tidak ada sama sekali. 


\section{d. Ruang Kuliah}

Evaluasi terhadap ruang kuliah dalam hal ini meliputi kondisi bangunan ruang kuliah, penerangan, pencahayaan, dan sirkulasi udara di ruang kuliah, kondisi kebersihan ruang kuliah, serta kondisi umum ruang perkuliahan.

Dilihat dari kondisi bangunan ruang kuliah, diketahui bahwa dari 30 orang sampel guru, 21 orang $(70 \%)$ menyatakan kondisi bangunan ruang kuliah cukup baik, 5 orang (16,67\%) menyatakan kurang baik, 4 orang $(13,33 \%)$ menyatakan baik, dan yang menyatakan sangat jelek tidak ada sama sekali. Dilihat dari penerangan, pencahayaan, dan sirkulasi udara di ruang kuliah, diketahui bahwa 22 orang (73,34\%) menyatakan kondisi penerangan, pencahayaan, dan sirkulasi udara di ruang kuliah cukup baik, 4 orang $(13,33 \%)$ menyatakan baik, 4 orang (13,33\%) menyatakan kurang baik, dan yang menyatakan sangat jelek tidak ada sama sekali.

Dilihat dari kondisi kebersihan ruang kuliah, diketahui bahwa 20 orang $(66,67 \%)$ menyatakan kondisi kebersihan ruang kuliah cukup bersih, 6 orang $(20 \%)$ menyatakan bersih, 3 orang (10\%) menyatakan kotor, dan yang menyatakan sangat kotor 1 orang $(3,33 \%)$. Dilihat dari kondisi umum ruang perkuliahan, diketahui bahwa 18 orang (60\%) menyatakan kondisi umum ruang perkuliahan cukup kondusif, 8 orang $(26,67 \%)$ menyatakan kondusif, 4 orang $(13,33 \%)$ menyatakan kurang kondusif, dan yang menyatakan sangat kurang kondusif tidak ada sama sekali.

\section{e. Fasilitas Penunjang Proses Pembelajaran}

Evaluasi terhadap fasilitas penunjang proses pembelajaran dalam hal ini meliputi kondisi fasilitas perkulihan, keberadaan ICT/Multimedia di ruang perkuliahan, dan penggunaan ICT/Multimedia yang ada di ruang kuliah.

Dilihat dari kondisi fasilitas perkulihan (whiteboard, spidol, OHP, dan lain-lain), diketahui bahwa dari 30 orang sampel guru, 10 orang $(33,33 \%)$ menyatakan kondisi fasilitas perkuliahan cukup memadai, 10 orang $(33,33 \%)$ menyatakan kurang memadai, 9 orang (30\%) menyatakan

memadai, dan yang menyatakan sangat kurang memadai hanya 1 orang (3,34\%). Dilihat dari kondisi keberadaan ICT/Multimedia (TV, Komputer, 
VCD, OHP, dll) di ruang perkuliahan, diketahui bahwa 16 orang $(53,33 \%)$ menyatakan bahwa ICT/Multimedia tidak ada sama sekali, 8 orang $(26,67 \%)$ menyatakan keberadaan ICT/Multimedia masih kurang, 4 orang $(13,33 \%)$ menyatakan cukup, dan yang menyatakan lengkap hanya 2 orang $(6,67 \%)$.

Dilihat dari penggunaan ICT/Multimedia (TV, Komputer, VCD, OHP, dll) yang ada di ruang kuliah, diketahui bahwa 15 orang (50\%) menyatakan bahwa ICT/Multimedia tidak difungsikan karena tidak ada, 6 orang $(20 \%)$ menyatakan sering difungsikan, 5 orang (16,67\%) menyatakan jarang difungsikan, dan 4 orang (13,33\%) menyatakan hanya difungsikan kadang-kadang.

\section{f. Pelayanan Akademik dan Administrasi}

Evaluasi terhadap pelayanan akademik dan administrasi dalam hal ini meliputi kualitas pelayanan akademik yang diberikan, cara pengelola program merespon kesulitan akademik yang dihadapi mahasiswa, perhatian pengelola program terhadap kebutuhan dan minat mahasiswa, perhatian personal yang didapatkan mahasiswa, kualitas pelayanan administrasi yang diberikan, kesediaan pegawai administrasi dalam memberikan pelayanan administrasi kepada mahasiswa, serta kemudahan mahasiswa untuk memperoleh informasi tentang nilai/kelulusan mata kuliah yang diikuti.

Dilihat dari kualitas pelayanan akademik yang diberikan, diketahui bahwa dari 30 orang sampel guru, 24 orang (80\%) menyatakan bahwa kualitas pelayanan akademik yang diberikan sudah memuaskan dan 6 orang $(20 \%)$ menyatakan tidak memuaskan. Dilihat dari cara pengelola program dalam merespon kesulitan akademik yang dihadapi mahasiswa, diketahui bahwa 15 orang (50\%) menyatakan bahwa pihak pengelola program hanya membantu seperlunya, 9 orang $(30 \%)$ menyatakan membantu dengan simpatik, dan 2 orang $(6,67 \%)$ menyatakan pengelola program acuh tak acuh.

Dilihat dari perhatian pengelola program terhadap kebutuhan dan minat mahasiswa, diketahui bahwa 13 orang (43,33\%) menyatakan bahwa perhatian pengelola program terhadap kebutuhan dan minat mahasiswa sudah baik, 8 orang $(26,66 \%)$ menyatakan biasa-biasa saja, 5 orang 
(16,66\%) menyatakan sangat baik. Dilihat dari perhatian personal yang didapatkan mahasiswa dari pengelola program, diketahui bahwa 17 orang $(56,67 \%)$ menyatakan bahwa perhatian personal yang didapatkan mahasiswa dari pengelola program sudah baik, 8 orang $(26,67 \%)$ menyatakan sangat baik, 5 orang (16,66\%) menyatakan biasa-biasa saja, dan yang menyatakan kurang perhatian tidak ada sama sekali.

Dilihat dari kualitas pelayanan administrasi yang diberikan, diketahui bahwa 19 orang $(63,33 \%)$ menyatakan bahwa kualitas pelayanan administrasi yang diberikan sudah cukup memuaskan, 8 orang $(26,67 \%)$ menyatakan memuaskan, 2 orang (6,67\%) menyatakan kurang memuaskan, dan 1 orang (3,33\%) menyatakan tidak memuaskan. Dilihat dari kesediaan pegawai administrasi dalam memberikan pelayanan administrasi kepada mahasiswa, diketahui bahwa 14 orang (46,67\%) menyatakan bahwa kesediaan pegawai administrasi dalam memberikan pelayanan administrasi kepada mahasiswa sudah baik, 10 orang $(33,33 \%)$ menyatakan cukup, 6 orang $(20 \%)$ menyatakan sangat baik, dan yang menyatakan kurang baik tidak ada sama sekali.

Dilihat dari kemudahan mahasiswa untuk memperoleh informasi tentang nilai/kelulusan mata kuliah yang diikuti, diketahui bahwa 23 orang $(76,67 \%)$ menyatakan mengalami kemudahan dalam memperoleh informasi tentang nilai/kelulusan mata kuliah yang diikuti dan 7 orang $(23,33 \%)$ menyatakan mengalami kesukaran.

\section{Dampak yang Dirasakan oleh Guru dari Pelaksanaan Program}

Secara umum, hasil evaluasi terhadap dampak program Peningkatan Kualifikasi Guru Madrasah baik terhadap peningkatan kompetensi mengajar guru, peningkatan karir guru, peningkatan kesejahteraan guru, maupun terhadap kemungkinan penerapan materi perkuliahan yang diperoleh sebagian besar sudah sesuai dengan yang diharapkan.

Dilihat dari dampak program Peningkatan Kualifikasi Guru Madrasah terhadap peningkatan kompetensi mengajar guru, diketahui bahwa dari 30 orang sampel guru, 26 orang $(86,67 \%)$ menyatakan adanya dampak program terhadap peningkatan kompetensi mengajar guru dan 4 
orang (13,33\%) menyatakan tidak ada dampaknya. Dilihat dari dampak program Peningkatan Kualifikasi Guru Madrasah terhadap peningkatan karir guru, diketahui bahwa 29 orang $(96,67 \%)$ menyatakan adanya dampak program ini terhadap peningkatan karir guru dan 1 orang $(3,33 \%)$ menyatakan tidak ada dampaknya.

Dilihat dari dampak program Peningkatan Kualifikasi Guru Madrasah terhadap peningkatan kesejahteraan guru, diketahui bahwa 27 orang $(90 \%)$ menyatakan adanya dampak program terhadap peningkatan kesejahteraan guru dan 3 orang (10\%) menyatakan tidak ada dampaknya. Dilihat dari dampak program Peningkatan Kualifikasi Guru Madrasah terhadap kemungkinan penerapan materi perkuliahan yang diperoleh, diketahui bahwa 12 orang (40\%) menyatakan bahwa materi perkuliahan yang diperoleh dapat diterapkan, 11 orang (36,67\%) menyatakan sebagian besar dapat diterapkan, 5 orang $(16,67 \%)$ menyatakan sebagian kecil dapat diterapkan, dan 2 orang $(6,66 \%)$ menyatakan tiadk dapat diterapkan.

\section{Pembahasan}

Berdasarkan hasil evaluasi terhadap pelaksanaan program peningkatan kualifikasi guru madrasah menunjukkan bahwa secara umum sebagian besar sudah berjalan sesuai dengan yang direncanakan. Akan tetapi, jika dilihat satu persatu, khusus pada proses pelaksanaannya masih ada beberapa hal yang belum sepenuhnya sesuai dengan yang direncanakan.

Berkaitan dengan proses pelaksanaan program peningkatan kualifikasi guru madrasah, baik pada tahap persiapan program dan proses pembelajaran yang dilaksanakan beberapa diantaranya masih belum sepenuhnya sesuai harapan. Pada tahap persiapan program, khususnya pada prosedur penyaluran dana, ada keragaman yang cukup tinggi dalam waktu penerimaan bantuan, sebagian besar responden merasakan ketidaksesuaian jumlah bantuan yang diterima, bantuan yang diterima tidak melalui prosedur pengiriman langsung ke rekening pribadi, serta mekanisme penyaluran dana masih belum sepenuhnya efektif, adanya potongan oleh bank maupun oleh LPTK. 
Pada proses pembelajaran, baik dilihat dari kesiapan dosen dalam mengajar, kualitas pengelolaan perkuliahan, metode pembelajaran, ruang kuliah, fasilitas penunjang proses pembelajaran, sarana dan prasarana, lingkungan kampus, maupun pelayanan akademik dan administrasi, sebagian besar masih belum sesuai dengan rencana. Dilihat dari kesiapan dosen dalam mengajar, hanya 10\% yang menyatakan kesesuaian bidang keahlian dosen dengan mata kuliah yang diajarkan sudah mencapai 100\%, hanya $20 \%$ yang menyatakan $100 \%$ dosen sudah berkualifikasi pendidikan S2, hanya 23,33\% yang menyatakan kesiapan dosen terhadap dokumen perangkat pembelajaran mencapai lebih dari 90\%, hanya 20\% yang menyatakan kesiapan dosen dalam merancang tugas-tugas mencapai lebih dari $90 \%$, serta hanya sebagian kecil dosen yang mempunyai waktu untuk memberikan bimbingan akademik di luar jam kuliah. Dilihat dari kualitas pengelolaan perkuliahan, hanya $20 \%$ yang menyatakan penerapan program remedial, pengayaan, dan percepatan dalam implementasi prinsip-prinsip pembelajaran tuntas oleh dosen sudah baik. Dilihat dari penggunaan metode pembelajaran, menurut sebagian besar responden hanya sebagian kecil dosen yang mengajar dengan metode bervariasi. Dilihat dari ruang kuliah, hanya 13,33\% yang menyatakan ruang kuliah dalam kondisi baik, hanya $13,33 \%$ yang menyatakan penerangan, pencahayaan, dan sirkulasi udara di ruang kuliah dalam kondisi baik, hanya 20\% yang menyatakan ruang kuliah dalam kondisi bersih, serta hanya 26,67\% yang menyatakan ruang perkuliahan kondusif. Dilihat dari fasilitas penunjang proses pembelajaran, hanya 30\% yang menyatakan kondisi fasilitas perkulihan memadai, hanya $6,67 \%$ yang menyatakan kondisi keberadaan ICT/Multimedia lengkap, kalaupun ada sebanyak 50\% responden menyatakan bahwa ICT/Multimedia tersebut tidak difungsikan. Dilihat dari pelayanan akademik dan administrasi, sebanyak 6,67\% responden menyatakan pengelola program acuh tak acuh dalam merespon kesulitan akademik yang dihadapi mahasiswa.

Sangat berbeda dengan hasil evaluasi terhadap proses pelaksanaannya, dampak yang dirasakan oleh guru dari program peningkatan kualifikasi guru madrasah ini sebagian besar sudah sesuai dengan yang diharapkan, baik dilihat dari dampaknya terhadap 
peningkatan kompetensi mengajar guru, peningkatan karir guru, dan peningkatan kesejahteraan guru. Hanya saja dilihat dari dampak program terhadap kemungkinan penerapan materi perkuliahan yang diperoleh, hanya 40\% responden yang menyatakan bahwa materi perkuliahan yang diperoleh dapat diterapkan.

\section{Simpulan}

Berdasarkan hasil penelitian dan pembahasan di atas, dapat diambil kesimpulan sebagai berikut:

1. Proses pelaksanaan program peningkatan kualifikasi guru madrasah di Sumatera Selatan secara umum sebagian besar sudah berjalan sesuai dengan yang direncanakan. Akan tetapi, jika dilihat satu persatu, khusus pada proses pelaksanaannya masih ada beberapa hal yang belum sepenuhnya sesuai dengan yang direncanakan. Hal-hal yang masih belum sesuai dengan yang direncanakan nampak baik pada tahap persiapan program maupun pada proses pembelajaran.

2. Dampak yang dirasakan oleh guru madrasah dengan diterapkannya program peningkatan kualifikasi guru ini terlihat pada peningkatan kompetensi mengajar guru, peningkatan karir guru, serta peningkatan kesejahteraan guru. Hanya saja dilihat dari dampak program terhadap kemungkinan penerapan materi perkuliahan yang diperoleh, hanya $40 \%$ responden yang menyatakan bahwa materi perkuliahan yang diperoleh dapat diterapkan.

\section{Daftar Pustaka}

Daradjat, Z., et al. 1996. Pendidikan Islam. Jakarta: Bumi Aksara Bekerjasama dengan Direktorat Jenderal Pembinaan Kelembagaan Agama Islam, Departemen Agama RI.

Djamas, N. 2005. "Posisi Madrasah Di Tengah Perubahan Sistem Pendidikan Islam". Jurnal Edukasi. Volume 3, Nomor 1, JanuariMaret 2005. Hlm. 23-29. 
Idi, A. 2006. "UU No. 14/2005 Tentang Guru/Dosen: Antara Cita dan Fakta", Intizar: Jurnal Kajian Agama Islam dan Masyarakat, Vol. 12/No.2/Desember 2006. Hlm. 133-148.

Kementerian Agama RI. 2007. Buku Statistik Pendidikan Islam TP 2006/2007. Jakarta: Direktorat Jenderal Pendidikan Islam

Kunandar. 2007. Guru Profesional: Implementasi Kurikulum Tingkat Satuan Pendidikan (KTSP) dan Persiapan Menghadapi Sertifikasi Guru, Jakarta: PT. Raja Grafindo Persada.

Stufflebeam, Daniel L. \& Shinkfield, A. J. 1985. Systematic Evaluation. USA: Kluwer-Nijhoff Publishing. 